\title{
The Decision of Married Woman to Inspect IVA Test in Deli Serdang, Indonesia
}

\author{
Nurbaity ${ }^{1}$, Zulfendri $^{2}$, R. Kintoko Rochadi ${ }^{2}$ \\ ${ }^{1}$ Master Student in Universitas Sumatera Utara (USU), Medan, Indonesia \\ ${ }^{2}$ Lecturer in Universitas Sumatera Utara (USU), Medan, Indonesia \\ Email: nurbaity.skm@gmail.com
}

\begin{abstract}
:
This study aims to find out the decision of married woman to inspect IVA Test in Deli Serdang, Indonesia. This type of research is an analytical survey research with cross sectional approach (Arikunto, 2010), which aims to determine the relationship of power relations with the low coverage of IVA Test coverage. The result shows that the dominance of power in the household, socio-economic that has a relationship with the decision making to conduct an IVA test in Deli Serdang Regency, It can be concluded several things.

Keywords:

gender; power relation; married women; IVA Test; Deli Serdang Regency
\end{abstract}

\section{Introduction}

In Deli Serdang Regency, the level of female labor force participation was 39.21\% while the level of male labor force participation was $83.28 \%$. The low level of female labor force participation is directly proportional to the female unemployment rate that is greater than men at $8.32 \%$ while the unemployment rate of men is at 5.47\% (BPS Deli Serdang District 2017).

Based on Infodatin (2014), active participation of men who use contraceptives is only $6.09 \%$ while the participation of women who use contraceptives is $93.66 \%$. According to Hendarso (2008: 72) in terms of these conditions, women bear a double burden compared to men, namely productive and reproductive roles. This condition causes the complexity of women's problems related to their reproductive functions, whether physical, psychological, or social.

Based on the results of research by Kuponiyi and Alade (2007), it shows that decision making about reproductive health in the family is strongly influenced by social cultural, economic factors in the family. The findings of a study conducted by Meliasari, D. (2015) stated that of the 30 respondents who received husband's support to conduct an IVA Test, 23 respondents $(76.7 \%)$ conducted an IVA Test, while of 64 respondents who did not have the husband's support To do an IVA test, all respondents (100\%) did not do an IVA test.

Speizer, I. S., Whittle, L., \& Carter, M. (2005) suggested that gender inequality in reproductive decision making is a key element of the social context of reproductive health. Gender based inequality can contribute to poor reproductive health, by inhibiting women from making decisions for reproductive health, limiting women's access to reproductive health services, which can result in an increased risk of contracting HIV infection (Human Immunodeficiancy Virus) and Sexually Transmitted Infections (IMS) others. From the results of tha research as a whole it was found that $25 \%$ of women and $28 \%$ of men revealed that men themselves must be responsible for decision making related to reproductive health.

In North Sumatra, which is dominated by Batak (41.93\%), Javanese (32.62\%), Nias (6.36\%), Malay (5.92\%), the general public still adheres to patrilineal lineage patterns, according to adat habit, the role of the husband is very influential in decision making in a family (Wikipedia, 2010). The tribes inhabiting Deli Serdang Regency are the Malay, Batak, Javanese, Karo and Minang tribes (https://www.deliserdangmall.com/majalah/ini-dia-5-suku-yang-tinggal-di-deli- 
serdang- and culture, accessed on Monday July 01 2019). North Sumatera, the majority of whose ethnicity adheres to patrilineal lineage patterns, had lower IVA test coverage (7\%) in 2016 (www.humas.pemkomedan.go.id, seen June 20, 2019). Compared to West Sumatera Province which adheres to the matrilineal line pattern, the IVA test coverage in 2016 ranks eighth highest in Indonesia (7.16\%), even for the city of Padang itself, the IVA test coverage is 72.16 percent (A. Deska, 2018 ).

Based on preliminary surveys in Deli Serdang Regency Health Office it is known that the number of mothers who did early detection of cervical cancer through the IVA method in 2017 was 7559 people $(6.64 \%)$ out of 113,749 people who were subjected to IVA test screening $(<30$ 50 years), with the results of the examination found 9 (nine) mothers detected positive IVA, 37 people with suspicious results of cancer, while there were 124 people with abnormal test results and 2 people positive for cervical cancer (IVA test report Deli Serdang District Health Office, 2017). In 2018, IVA test coverage will increase to $16.2 \%$. However, this figure is still far from the national target set by the Ministry of Health by $50 \%$ until the end of 2019 .

\section{Review of Literature}

\subsection{Gender}

Most societies have not been able to distinguish gender and gender in terms of definition. Society tends to assume that gender and gender are the same thing. The experts have put forward the true meaning related to gender definition, but not infrequently there are still many who are wrong in interpreting it.

Gender is a biological-anatomical character (specifically the reproductive and hormonal system) followed by physiological characteristics of the body, which determine whether a person is male or female (Indonesian Ministry of Health, 2007). Koester, D in Robinson, Jennifer, L., et al. (2017) suggested that gender refers to a series of roles, behaviors, norms set by society as something that is suitable for women and men. According to Knudson-Martin \& Mahoney in Mbweza, E. (2007), gender is an important socio-cultural variable that determines the role of husband and wife in marital relationships in many societies. Husbands and wives apply traditional gender norms in most of their interactions.

Gender refers to the different roles and social responsibilities between women and men that are shaped by culture. These differences in roles and social responsibilities are sometimes related to gender ability. Based on this then the community makes it as a basis for distinguishing the characteristics, status, values that are considered appropriate for a man or woman (Ministry of Health, 2006).

\subsection{Gender Issues in Reproductive Health}

Gender issues began to be discussed at the 1994 International Conference on Population and Development, then continued at the Fourth World Conference on Women in Beijing in 1995 and ICPD + 5 (1999) at The Haque forum. Various key gender issues were found to be strongly related to reproductive health. In Indonesia, at the National Workshop on Reproductive Health in Jakarta (1996), it was agreed that the definition of Reproductive Health refers to the WHO definition, namely "a state of complete physical, mental and social well-being, not solely free from disease and disability; in aspects related to the reproductive system, and its functions and processes "(Ministry of Health, Republic of Indonesia, 2007).

According to Agassi in Daulay, H (2001) revealed that if a husband and wife have the same power in the economic field and control over vital resources, then only the balance of women's status in the household can be obtained. In other words, if women do not have the things mentioned above, then the husband will dominate power in the household. 


\subsection{Cervical Cancer}

Cervical Cancer is a type of cancer that occurs in the cervix (cervix), which is the lower part of the uterus that is connected to the vagina. Cervical cancer starts when healthy cells acquire genetic changes (mutations) that cause them to turn into abnormal cells.

Causes of cervical cancer. Various types of Human Papilloma Virus (HPV), sexually transmitted infections, play a role in causing most cervical cancers. When exposed to HPV, a woman's immune system usually prevents the virus from doing damage. However, in a small group of women, the virus lasts for years, contributing to the process that causes some cells on the surface of the cervix to become cancerous cells. What causes cervical cancer is still not known with certainty, but in general HPV plays a very important role in causing cervical cancer. There are several risk factors associated with cervical cancer.

\subsection{IVA Test}

IVA test was first discovered by Sankaranarayanan et al. Early detection using the IVA method is easy to do, the cost of an inexpensive examination, the results are quickly known, has an accurate level of specificity and sensitivity, can be done by doctors, midwives, who have received training. IVA test is done by applying 3-5\% acetic acid to the cotton stick and rubbed into the cervix / cervix (Permenkes, 2015). After the cervix is rubbed with acetic acid, it is then observed and observed for a while, after which an evaluation is carried out. The results of IVA examination, are grouped as follows normal ie if the results of the IVA test are negative, inflammation / cervical / atypical ie the picture is not typical of the cervix due to infection, both acute and chronic in the cervix, positive IVA is the presence of white patches / pre-cancerous lesions, suspicious of cervical cancer. IVA examination is a screening program to find cervical cancer. Because now many cervical cancers are found at an advanced stage.

\section{Research Methods}

This type of research is an analytical survey research with cross sectional approach (Arikunto, 2010), which aims to determine the relationship of power relations with the low coverage of IVA Test coverage. This research is conducted in seven districts in Deli Serdang Regency. The reason for choosing research locations in Deli Serdang Regency is because socialization and implementation of early cervical cancer detection have been carried out with IVA method in each puskesmas, in collaboration with village and sub-district governments, holding IVA stalls to facilitate IVA test inspection services, in collaboration with the Family Empowerment and Welfare Mover Team (TP. PKK) Sub-district, but the level of attendance of women of childbearing age (WUS) in the early detection of cervical cancer is still at a figure $(16.2 \%)$, very far from the number targeted by the Ministry of Health $(50 \%)$. Of all women of childbearing age who do early detection of cervical cancer through the IVA method in Deli Serdang district, there are 26 women with suspect cervical cancer. Some have received therapy through cryotherapy and were referred to Deli Serdang Regency Hospital. The time of this study began in the initial survey of August 2018 until completion.

\section{Discussion}

This research was conducted in 7 districts in Deli Serdang Regency. Namely Sunggal District, Percut Sei Tuan District, STM Hilir District, Patumbak District, Batang Kuis District, Sibolangit District and Hamparan Perak District. Among the 7 sub-districts which have the farthest distance to the Regency Capital are Sibolangit sub-district (Central Statistics Agency of Deli Serdang Regency, 2017). 
Deli Serdang Regency occupies an area of 2,497.72 km2 which consists of 22 districts and 394 villages / wards. Deli Serdang is one of the districts in the East Coast region of North Sumatra with a population of $2,072,521$ people with a population density of 830 people per $\mathrm{km} 2$. The total male population is 1,043,114 inhabitants and the total female population is 1,029,407 (Central Statistics Agency of Deli Serdang Regency, 2017).

Deli Serdang Regency has a lot of cultural diversity. Based on field observations, information was obtained that there were a number of ethnic groups living in the Deli Serdang district, including Javanese, Batak, Karo, Malay, Simalungun, Mandailing, Minang, although the indigenous tribes of Deli Serdang Regency were Malay.

Deli Serdang Regency has 34 main Puskesmas scattered in 22 sub-districts in the Deli Serdang Regency. In fact, there is one district that has 3 main health centers in order to meet the community's need for health services. Coverage of IVA Test services is not directly proportional to the availability of health facilities in Deli Serdang Regency, only by $16.2 \%$, still very far from the national target of $50 \%$.

Deli Serdang Regency Government continues to strive to provide optimal health services to the community in Deli Serdang Regency, particularly in relation to the IVA test program which has become a national program to eradicate cervical cancer in women by creating IVA stalls to better reach the community's need for IVA services test.

Univariate results of the age variable of respondents in the category of more than 30 years were 110 people $(90.9 \%)$ and in the category of less than 30 years as many as 11 people $(9.1 \%)$. The most common tribes in this study were 71 Javanese (58.7\%), then Mandailing as many as 13 people (10.7\%), Karo as many as 11 people $(9.1 \%)$ and at least Simalungun, Sunda, Ambon and Dayak. as many as 1 person $(0.8 \%)$. Can be seen in the following table:

Table 1. Frequency Distribution of Age and Education Characteristics of Respondents

\begin{tabular}{lll}
\hline Variable & Total (Person) & Percentage $(\%)$ \\
\hline Age & & \\
$<30$ years old & 11 & 9,1 \\
$\geq 30$ years old & 110 & 90,9 \\
Ethnic & & \\
Ambon & 1 & 0,8 \\
Batak & 6 & 5,0 \\
Dayak & 1 & 0,8 \\
Jawa & 71 & 58,7 \\
Karo & 11 & 9,1 \\
Mandailing & 13 & 10,7 \\
Melayu & 8 & 6,6 \\
Minang & 4 & 3,3 \\
Padang & 4 & 3,3 \\
Simalungun & 1 & 0,8 \\
Sunda & 1 & 0,8 \\
\hline Total & 121 & 100,0 \\
\hline
\end{tabular}

\subsection{Description of Variables Domination of Power in the Household}

The univariate results of the authority dominance variable that took the most authority were husband of 63 people $(52.1 \%)$, husband and wife as many as 41 people $(33.9 \%)$ and wives as many as 17 people $(14.0 \%)$. Can be seen in the following table: 
Table 2. Frequency Distribution Characteristics of Authority Dominance

\begin{tabular}{lll}
\hline Variable & Total (Person) & Percentage $(\%)$ \\
\hline Domination of authority & 63 & \\
Husband & 17 & 52,1 \\
Wife & 41 & 14,0 \\
Husband and wife & 121 & 33,9 \\
Total & 100,0 \\
\hline
\end{tabular}

\subsection{Description of Socio-Economy Variables}

Univariate results of the wife's work variable in the category of not working as many as 66 people $(54.5 \%)$ and the category of work as many as 55 people $(45.5 \%)$. The variable of husband's income in the high category is 71 people (58.7\%) and in the low category is 50 people $(41.3 \%)$. The variable of wife's income in the low category is 106 people $(87.6 \%)$ and in the high category is 15 people $(12.4 \%)$. The education variables of the respondents were mostly in the SLTP / SLTA category as many as 84 people (69.4\%), S1 / S2 / S3 education as many as 26 people $(21.5 \%)$, non-school / elementary education as many as 7 people $(5.8 \%)$ and at least 4 people in the D1 / D3 category (3.3\%). variable knowledge category lacking as many as 17 people $(14.0 \%)$, enough categories as many as 76 people $(62.8 \%)$ and good categories as many as 28 people $(23.1 \%)$. Can be seen in the following table:

Table 3. Frequency Distribution of Job Characteristics and Earnings

\begin{tabular}{lll}
\hline Variable & Total (Person) & Percentage (\%) \\
\hline Wife's work & & \\
$\quad$ Does not work & 66 & 54,5 \\
$\quad$ Work & 55 & 45,5 \\
Husband's income & & \\
$\quad$ Low & 50 & 41,3 \\
$\quad$ High & 71 & 58,7 \\
Wife's income & & \\
Low & 106 & 87,6 \\
High & 15 & 12,4 \\
Education & & \\
No School / Elementary School & 7 & 5,8 \\
Senior High School & 84 & 69,4 \\
D1/D3 & 4 & 3,3 \\
S1/S2/S3 & 26 & 21,5 \\
Knowledge & & \\
Less & 17 & 14,0 \\
Enough & 76 & 62,8 \\
$\quad$ Well & 28 & 23,1 \\
Total & 121 & 100,0 \\
\hline
\end{tabular}

\subsection{Description of the Variable IVA Test Decision Making}

Univariate results of the IVA examination variables of respondents who did IVA examinations were 48 people $(39.7 \%)$ and those who did not do IVA examinations were 73 people $(60.3 \%)$. Can be seen in the following table: 
Table 5. Frequency Distribution of IVA Examination Characteristics

\begin{tabular}{lll}
\hline Variable & Total (Person) & Percentage $(\%)$ \\
\hline IVA Test & & \\
No & 73 & 60,3 \\
Yes & 48 & 39,7 \\
Total & 121 & 100,0 \\
\hline
\end{tabular}

\subsection{Relationship between Authority Domination and IVA Examination}

The results of the analysis of the relationship between the independent variables, namely the dominance of authority with the dependent variable, namely the decision to conduct an IVA Test. It is known that of the 63 husbands who made the decision as many as 45 people $(70.3 \%)$ of them did not do an IVA examination and as many as 18 people $(28.6 \%$ did an IVA Test. 9 people $(52.9 \%)$ did not do IVA examinations as many as 8 people $(47.1 \%)$, the dominance of husband and wife were 41 people, who did IVA examinations as many as 21 people $(51.2 \%)$ and who did not do IVA Test as many as 20 people (48.8\%).

The results of the analysis of the relationship of authority dominance with IVA Test using the chi-square test obtained $\mathrm{p}$ value $=0.034(\mathrm{p}<0.05)$ so that it can be seen that there is a relationship between authority dominance and IVA Test. Can be seen in the following table:

Table 6. Relationship between Authority Domination and IVA Test

\begin{tabular}{|c|c|c|c|c|c|c|c|}
\hline \multirow{3}{*}{ Variable } & \multicolumn{6}{|c|}{ IVA Test } & \multirow{3}{*}{$P$} \\
\hline & \multicolumn{2}{|c|}{ No } & \multicolumn{2}{|l|}{ Yes } & \multicolumn{2}{|c|}{ Total } & \\
\hline & $\mathrm{N}$ & $\%$ & $\mathrm{n}$ & $\%$ & $\mathrm{n}$ & $\%$ & \\
\hline \multicolumn{8}{|c|}{ Domination of authority } \\
\hline Husband & 45 & 70,3 & 18 & 28,6 & 63 & 100 & \\
\hline Wife & 8 & 47,1 & 9 & 52,9 & 17 & 100 & 0,034 \\
\hline Husband and wife & 20 & 48,8 & 21 & 51,2 & 41 & 100 & \\
\hline
\end{tabular}

\subsection{Socio-Economic Relations with IVA Test}

Based on the results of the study note that the work status of wives who do not work as many as 66 people, respondents who did IVA examinations were 25 people $(37.9 \%)$ and as many as 41 people $(62.1 \%)$ who did not do IVA Test. The working status of working wives is 55 people, 23 people $(41.8 \%)$ and $32 \mathrm{~A}(58.2 \%)$ of respondents who did IVA examination did not do IVA Test. The results of the analysis of the relationship of the wife's work status with IVA Test using the chi-square test obtained $\mathrm{p}$ value $=0.695(\mathrm{p}>0.05)$ so that it can be seen that there is no relationship between the wife's work status with IVA Test.

Based on the results of the study note that the husband's income in the low category of 50 people, as many as 18 people $(36.0 \%)$ of whom did an IVA Test and as many as 32 people $(64.0 \%)$ who did not do an IVA Test. The income of the husband in the high category was 71 people, respondents who did IVA Test were 30 people (42.3\%) and 41 people $(57.7 \%)$ who did not do IVA checks. The results of the analysis of the relationship between husband's income and IVA Test using the chi-square test obtained $\mathrm{p}$ value $=0.489(\mathrm{p}>0.05)$ so that it can be seen that there is no relationship between husband's income and IVA Test.

Based on the results of the study note that the wife's income in the low category as many as 106 people, as many as 43 people (40.6\%) of whom did an IVA Test and as many as 63 people $(59.4 \%)$ who did not do an IVA Test. The wife's income in the high category is 15 people, respondents who do IVA Test are 5 people $(33.3 \%)$ and 10 people $(66.7 \%)$ who do not do IVA Test. The results of the analysis of the relationship of wife's income with IVA Test using the chisquare test obtained $\mathrm{p}$ value $=0.592(\mathrm{p}>0.05)$ so that it can be seen that there is no relationship between wife's income and IVA Test. 
Based on the results of research on educational variables, it is known that 91 respondents in the low category who did IVA Test were 38 people (41.8\%) and 53 people $(58.2 \%)$ who did not do IVA Test. Education of respondents in the high category were 30 people who did IVA Test as many as 10 people $(33.38 \%)$ and as many as 20 people $(66.7 \%)$ who did not do IVA examinations. The results of the analysis of the relationship of education with IVA Test using the chi-square test obtained $\mathrm{p}$ value $=0.413(\mathrm{p}>0.05)$ so that it can be seen that there is no relationship between education with IVA Test.

Based on the results of the study note that the knowledge in the category of lacking as many as 17 people, as many as 2 people $(11.8 \%)$ of whom did an IVA Test and as many as 15 people $(88.2 \%)$ who did not do an IVA Test. 75 people have enough knowledge in the category, 28 people $(36.8 \%)$ and 48 people $(63.2 \%)$ have done no IVA Test. Knowledge in the good category was 28 people, respondents who did IVA Test were 18 people (64.3\%) and 10 people $(35.7 \%)$ who did not do IVA Test. The results of the analysis of the relationship of knowledge with IVA Test using the chi-square test obtained $\mathrm{p}$ value $=0.002(\mathrm{p}<0.05)$ so that it can be seen that there is a relationship between knowledge and IVA Test. Can be seen in the following table:

Table 7. Relationship of Wife's Work Status with IVA Test

\begin{tabular}{|c|c|c|c|c|c|c|c|}
\hline \multirow{3}{*}{ Variable } & \multicolumn{6}{|c|}{ IVA Test } & \multirow{3}{*}{$P$} \\
\hline & \multicolumn{2}{|c|}{$\mathrm{No}$} & \multicolumn{2}{|c|}{ Yes } & \multicolumn{2}{|c|}{ Total } & \\
\hline & $\mathrm{N}$ & $\%$ & $\mathrm{n}$ & $\%$ & $\mathrm{~N}$ & $\%$ & \\
\hline \multicolumn{8}{|c|}{ Wife's employment status } \\
\hline Does not work & 41 & 62,1 & 25 & 37,9 & 66 & 100 & \multirow{2}{*}{0,659} \\
\hline Work & 32 & 58,2 & 23 & 41,8 & 55 & 100 & \\
\hline \multicolumn{8}{|l|}{ Husband's income } \\
\hline Low & 32 & 64,0 & 18 & 36,0 & 50 & 100 & \multirow{2}{*}{0,489} \\
\hline High & 41 & 57,7 & 30 & 42,3 & 71 & 100 & \\
\hline
\end{tabular}

Table 8. Relationship of wife's work status with IVA Test

\begin{tabular}{|c|c|c|c|c|c|c|c|}
\hline \multirow{3}{*}{ Variable } & \multicolumn{6}{|c|}{ IVA Test } & \multirow{3}{*}{$P$} \\
\hline & \multicolumn{2}{|l|}{ No } & \multicolumn{2}{|l|}{ Yes } & \multicolumn{2}{|c|}{ Total } & \\
\hline & $\mathrm{N}$ & $\%$ & $\mathrm{n}$ & $\%$ & $\mathrm{~N}$ & $\%$ & \\
\hline \multicolumn{8}{|c|}{ Wife's income } \\
\hline Low & 63 & 59,4 & 43 & 40,6 & 106 & 100 & \multirow{2}{*}{0,592} \\
\hline High & 10 & 66,7 & 5 & 33,3 & 15 & 100 & \\
\hline \multicolumn{8}{|l|}{ Education } \\
\hline Low & 53 & 58,2 & 38 & 41,8 & 91 & 100 & \multirow{2}{*}{0,413} \\
\hline High & 20 & 66,7 & 10 & 33,3 & 30 & 100 & \\
\hline \multicolumn{8}{|l|}{ Knowledge } \\
\hline Less & 15 & 88,2 & 2 & 11,8 & 17 & 100,0 & \multirow{3}{*}{0,002} \\
\hline Enough & 48 & 63,2 & 28 & 36,8 & 76 & 100,0 & \\
\hline Well & 10 & 35,7 & 18 & 64,3 & 28 & 100,0 & \\
\hline
\end{tabular}

\section{Conclusion}

Based on the results of research on the dominance of power in the household and socioeconomic that has a relationship with the decision making to conduct an IVA Test in Deli Serdang Regency, it can be concluded several things.

Domination of power in the household. In this variable is closely related to decision making in the household, who is the most dominant decision making in the household. From the results of this study on this variable has a relationship with the decision to conduct an IVA Test. 
Socio-economic. In this variable, there are three variables that accompany it, namely education, income and knowledge. The results of the research analysis show that there is no relationship between education and income variables with the decision to make an IVA Test. While the variables that have a relationship with the decision to conduct an IVA Test are knowledge variables.

\section{References}

Angriani, S. D., Natosba, J., \& Girsang, B. M. (2019). Faktor determinan partisipasi perempuan usia berisiko dalam pemeriksaan inspeksi visual asam asetat (iva). Jurnal Kesehatan Masyarakat (JKM) CENDEKIA UTAMA, 7(1), 19-38.

Anugwom, E., \& Anugwom, K. (2016). Socio-cultural factors in the access of women to hiv/aids prevention and treatment services in south-southern Nigeria. Iranian journal of public health, 45(6), 754.

Beritasatu, (2018, 1 March). Kanker Serviks capai 21.000 Kasus di Indonesia. Accessed 15 January 2019, https://www.beritasatu.com/nasional/ 449444/kanker-serviks-capai-21000-kasusdi-indonesia

Chandra, B. (2008). Metodologi Penelitian Kesehatan. Jakarta: Buku Kedokteran EGC.

CNN, (2017, 27 August). Jumlah kasus kanker serviks Indonesia tertinggi ke-2 di dunia. Accessed 15 January 2019, from Error! Hyperlink reference not valid.

Damailia, H. T., \& Oktavia, T. R. (2015). Faktor-faktor determinan deteksi dini kanker serviks melalui metode pap smear pada Pasangan Usia Subur (PUS). Gaster: Jurnal Kesehatan, 12(2), 99-107.

Daulay, H. (2001). Pergeseran pola relasi gender di keluarga migran: studi kasus TKIW di Kecamatan Rawamarta, Kab. Karawang, Jawa Barat. Bandung: Galang Press.

Dalem, D. N. (2012). Faktor-Faktor Yang Mempengaruhi Bias Gender Penggunaan Kontrasepsi Pada Pasangan Usia Subur di Desa Dawan Kaler Kecamatan Dawan Klungkung. PIRAMIDA.

Departemen Kesehatan RI. (2006). Modul Pelatihan Pengarusutamaan Gender Bidang Kesehatan Bagi Pengelola Program Kesehatan, Subdit. Bina Perlindungan Kesehatan Reproduksi Direktorat Bina Kesehatan Ibu Ditjen Bina Kesehatan Masyarakat Departemen Kesehatan, Jakarta.

Departemen Kesehatan RI. (2007). Pengarus-utamaan Gender dalam Bidang Kesehatan. Direktorat Jenderal Bina Kesehatan Masyarakat Direktorat Bina Kesehatan Ibu, Jakarta.

Dewi, L. (2014). Faktor-Faktor Yang Berhubungan Dengan Perilaku Wanita Usia Subur Dalam Deteksi Dini Kanker Serviks Dengan Metode Pemeriksaan Inspeksi Visual Asam Asetat (IVA) Di Wilayah Kerja Puskesmas Tanjung Hulu Pontianak Timur Tahun 2014. Jurnal ProNers, 1(1).

Faqih, M. (2006). Analisis Gender dan Transformasi Sosial. Yogyakarta: Pustaka Pelajar.

Foucault, M. (2000). The subject and power in Power. In: Faubion, J. (ed.) Essential Works of Michel Foucault 1954-1984. New York: The New Press.

Gordon, S. P. (2013). Structure and cultural factors in marital power relations of Korean American families. The University of Texas at San Antonio.

Kompasiana, (2015, 21 June). Dominasi Dalam Rumah Tangga. Accessed 02 April 2019 https://www.kompasiana.com/daryani/550de371a33311ab2dba7d8a/dominasi-dalamrumah-tangga.

Komter, A. (1989). Hidden power in marriage. Gender $\mathcal{E}$ society, 3(2), 187-216.

Kuponiyi, F. A. and O. A. Alade. 2007. Gender Dynamics and Reproduction Decision Making Among Rural Families in Orire Local Government Area of Oyo State, Nigeria. Journal of social science 15(2): 101-104. 
Lemeshow, S., Hosmer, D. W., Klark, J. \& Lwangan, S. K. (eds) (1997). Besar Sampel Dalam Penelitian Kesehatan. Translated by: Pramono, D. E Kusnanto, H. Yogyakarta: Gadjah Mada University Press.

Lestari, R. P., \& Sarwinanti, S. (2017). Analisis Faktor Faktor Yang Mempengaruhi Minat Pemeriksaan Iva Di Puskesmas Tretep Kabupaten Temanggung. Doctoral dissertation, Universitas' Aisyiyah Yogyakarta.

Lubis, Y. F. (2015). Pengaruh Persepsi Dan Motivasi Wanita Usia Subur Terhadap Keikutsertaan Skrining Kanker Serviks Metode Inspeksi Visual dengan Asam Asetat (IVA) Di Wilayah Kerja Puskesmas Sidangkal Kecamatan Padangsidimpuan Selatan Tahun 2013 (Master's thesis).

Marmi, 2013. Kesehatan Reproduksi, Pustaka Pelajar, Yogyakarta.

Masturoh, E. (2016). Faktor-Faktor yang Mempengaruhi Wanita Usia Subur (WUS) dalam Melakukan Deteksi Dini Kanker Serviks Metode Inspeksi Visual Asam Asetat (IVA). Doctoral dissertation, Universitas Negeri Semarang.

Mbweza, E. (2007). Relationship power among married couples in Malawi: Implications for HIV prevention. University of Illinois at Chicago, Health Sciences Center.

Meliasari, D. (2015). Pengetahuan Dan Dukungan Suami Berhubungan Dengan Tindakan Pemeriksaan Iva Pada Pasangan Usia Subur (Pus) Di Desa Sunggal Kanan Tahun 2014. Jurnal Ilmiah PANNMED (Pharmacist, Analyst, Nurse, Nutrition, Midwivery, Environment, Dentist), 9(3), 226-230.

Nasihah, M., \& Sifia Lorna, B. (2013). Hubungan Antara Pengetahuan dan Pendidikan dengan Pelaksana Deteksi Dini Kanker Serviks Melalui IVA. Jurnal Midpro edisi 2/2013.

Nugroho, T., \& Setiawan, A. (2010). Kesehatan Wanita, Gender dan Permasalahannya. Yogyakarta: Nuha Medika.

Nurani, K. S., \& Ratnaningsih, S. (2017). Hubungan Pengetahuan Wanita Usia Subur Tentang Kanker Serviks Dengan Keikutsertaan Iva Test Di Puskesmas Umbulharjo Ii Yogyakarta. Doctoral dissertation, Universitas' Aisyiyah Yogyakarta.

Okun, B. S., \& Raz-Yurovich, L. (2019). Housework, Gender Role Attitudes, and Couples' Fertility Intentions: Reconsidering Men's Roles in Gender Theories of Family Change. Population and Development Review, 45(1), 169-196.

Olokodana, Mobolaji and Yeshi Habtemariam. 1998. Gender Equity, Equality and Empowerment of Women. InHand Book on Population and Family Life Education for Secondary School Teachers in Ethiopia. Edited by Markos Ezra \&Seyoum GebreSelassie, ddis Ababa.

Orock, A. N. (2015). Barriers that influence cervical cancer screening among female African immigrants. Doctoral dissertation, Trident University International.

Pertiwi, N. D. E., \& INDRIANI, I. (2015). Faktor-faktor yang berhubungan dengan kunjungan pemeriksaan IVA/pap smear pada ibu-ibu PKK di Dusun Tajem Depok Sleman. Doctoral dissertation, STIKES'Aisyiyah Yogyakarta.

Rasyid, N., \& Afni, N. (2017). Faktor-faktor yang Berhubungan dengan Perilaku Wus (Wanita Usia Subur) Tentang Deteksi Dini Kanker Leher Rahim Metode Iva (Inspeksi Visual Asam Asetat). PROMOTIF: Jurnal Kesehatan Masyarakat, 7(1), 63-75.

RI, K. K. (2014). Infodatin: Situasi dan analisis Keluarga berencana. Jakarta: Kementrian Kesehatan.

Riksani, R. (2016). Kenali Kanker Serviks Sejak Dini. Rapha Publishing, Yogyakarta.

Robinson, J. L., Narasimhan, M., Amin, A., Morse, S., Beres, L. K., Yeh, P. T., \& Kennedy, C. E. (2017). Interventions to address unequal gender and power relations and improve selfefficacy and empowerment for sexual and reproductive health decision-making for women living with HIV: A systematic review. PLoS One, 12(8), e0180699.

Roziqoh, R., \& Suparno, S. (2014). Pendidikan berperspektif gender pada anak usia dini. JPPM 
(Jurnal Pendidikan dan Pemberdayaan Masyarakat), 1(1), 86-100.

Sari, I. P. T. P. (2013). Pendidikan kesehatan sekolah sebagai proses perubahan perilaku siswa. Jurnal Pendidikan Jasmani Indonesia, 9(2).

Saslow D, Runowicz CD, Solomon D, Moscicki AB, Smith RA, Eyre HJ, Cohen C, American Cancer Society. American Cancer Society guidelines for the early detection of cervical neoplasia and cancer. CA Cancer J Clin2002, 52: 342-362

Silfia, N. N., \& Muliati, T. (2017). Hubungan Karakteristik, Pengetahuan dan Sikap dengan Pemeriksaan Inspeksi Visual Asam Asetat (IVA) pada Ibu Pasangan Usia Subur di Puskesmas Talise. Journal Center of Research Publication in Midwifery and Nursing, 1(2).

Simatauw, M. (2001). Gender dan pengelolaan sumber daya alam. Yayasan PIKUL.

Sulistiowati, E., \& Sirait, A. M. (2015). Pengetahuan tentang faktor risiko, perilaku dan deteksi dini kanker serviks dengan inspeksi visual asam asetat (iva) pada wanita di kecamatan bogor tengah, Kota Bogor. Buletin Penelitian Kesehatan, 42(3 Sep), 193-202.

Spizer, Ilene S, Lisa Whittle and Marion Carter. 2005. Gender Relations and Reproductive Decision Making in Honduras. International Family Planning Perspective 31(3):131-139

Suhaimi, D., Yunita, J., Abidin, Z., \& Riva'i, S. B. (2018). Pelaksanaan Program Deteksi Dini Kanker Cerviks (Ca Cervix) dengan Metode Inspeksi Visual Asam Asetat (IVA) di Kabupaten Kampar. Jurnal Kesehatan Komunitas, 4(2), 68-75.

Wikipedia, (t.t). Patriarki. Accessed 08 April 2019 https://id.wikipedia.org/wiki/Patriarki

Wikipedia, (t.t). Suku Bangsa di Sumatera Utara. Accessed 26 June 2019, from https://id.wikipedia.org/wiki/Suku_bangsa_di_Sumatra_Utara

World Health Organization (1999). An Assessment of Reproductive Health Needs in Ethiopia. World Health Organization, Geneva.

Wulandari, A., Wahyuningsih, S., \& Yunita, F. (2018). Faktor-faktor yang Berhubungan dengan Perilaku Pemeriksaan Inspeksi Visual Asam Asetat (IVA) pada Wanita Usia Subur (WUS) di Puskesmas Sukmajaya Tahun 2016. Jurnal Kedokteran Universitas Lampung, 2(2), 93 101. 